Johnson County Community College ScholarSpace@ JCCC

2010

\title{
U.S. Academic Library Consortia: A Review
}

Judith E. Guzzy

Johnson County Community College,jguzzy@jccc.edu

Follow this and additional works at: http://scholarspace.jccc.edu/sabbatical_projects

Part of the Business Administration, Management, and Operations Commons, and the Library and Information Science Commons

\section{Recommended Citation}

Guzzy, Judith E., "U.S. Academic Library Consortia: A Review" (2010). Sabbatical Projects. Paper 2.

http://scholarspace.jccc.edu/sabbatical_projects $/ 2$

This Article is brought to you for free and open access by the Sabbatical and Senior Scholar Projects at ScholarSpace @ JCCC. It has been accepted for inclusion in Sabbatical Projects by an authorized administrator of ScholarSpace @ JCCC. For more information, please contact bbaile14@jccc.edu. 


\section{U.S. Academic Library \\ Consortia: A Review}

A Sabbatical Project

By Judith E. Guzzy

Head, Technical Services

Billington Library

Johnson County Community College

2010 


\section{Acknowledgments}

The author wishes to thank the following individuals who gave of their limited time and infinite wisdom to assist with this project:

Judy Avrin, Coordinator, VALE

Donna Bacon, Executive Director, MOBIUS

John W. Berry, Executive Director, NILRC

Tim Bucknall, Assistant Director at the University of North Carolina, Greensboro and Founder and convener, Carolina Consortium

Cindy Clennon, Director, CARLI Electronic Resources

Scott Cohen, Director of Jackson State Community College, Tennessee

Greg Doyle, Electronic Resources Program Manager, Orbis Cascade Alliance

Robert Karen, Director of Member Services, WALDO

Karen Lange, Library Director, Laramie County Community College and Chair of the Wyoming

Community College Library Consortium

Brian McAtee, Librarian, Southeastern Community College

Gail Piotrowski, Librarian, Northcentral Technical College and Chair, WISPALS

Bob Pisciotta, Associate Director, Library Systems and Technical Services, University of Kansas

Medical Center and Co-chair, Kansas RLDC

Sarah Raley, Library Consortium Director, CCLC

Steve Rheinschmidt, Executive Director, ICCOC

John Schumacher, Electronic Resources Coordinator, SUNYConnect

Sara Zimmerman, Director, LOUIS 


\section{Introduction}

Few libraries are strangers to the concept of library consortia - institutional groups that collaborate to purchase software, systems, electronic resources, or other information-sharing products and services. Most academic libraries are members of at least one consortium, and many belong to multiple consortia. However, consortia vary widely in the services they offer and in how they are structured. This project, carried out in the fall of 2009 , focused on a review of academic library consortia that:

- Included two-year colleges, either exclusively or as part of a joint consortial arrangement with four-year colleges and universities; and

- Purchased or licensed databases and/or electronic resources as part of their consortial services.

The first step involved creating a list of consortia with the specified criteria. Consortia that are solely system-based (i.e., exist only to coordinate and operate an integrated library system for its members) were excluded; however those system-based consortia that also purchase databases were included. Former OCLC networks (regional consortia) were excluded, as were large, statewide consortia whose memberships include a variety of library types (e.g., public, K12 , hospitals, academic). Large, multi-type consortia merit a study devoted exclusively to these complex, multi-layered organizations.

The target consortia list was created from two major sources: (1) the International Coalition of Library Consortia (ICOLC) membership list; and (2) the Community and Junior College Listserv. After creating a list of candidate organizations, representatives at each 
consortium were contacted by e-mail to request a telephone interview. Fifteen responded positively to interview requests. Questionnaires were sent to consortia representatives prior to interviews (Appendix A) with responses completed during interviews. Answers to the questionnaire form the basis of this paper along with information gathered from relevant consortia Web pages.

Interview topics included membership, governance, fiscal agency, electronic resources, positive qualities, and goals and future challenges. Membership and governance structures are commonly described on consortia Web pages; because of this visibility, specific consortia are identified where these are discussed. For other topics (e.g., goals and challenges), consortia are not specifically identified to maintain confidentiality. In all, 16 individuals representing 15 consortia were interviewed.

Of the 15 consortia included in the project, 5 are two-year college consortia and 10 are two/four-year combination consortia. This latter group includes Kansas' academic library consortium, the Kansas Regent's Library Database Consortium (RLDC). Table 1 lists the consortia and states represented in this project.

\begin{tabular}{|l|}
\hline Table 1. Consortia Interviewed \\
\hline CARLI (Consortium of Academic and Research Libraries in \\
Illinois) - Illinois \\
Carolina Consortium - North/South Carolina \\
Community College Library Consortium (CCLC) - California \\
lowa Community College Online Consortium (ICCOC)* - lowa \\
Kansas Regents Library Database Consortium (RLDC) - Kansas \\
Library Deans and Directors Group of the State University and \\
Community College System of the Tennessee Board of Regents \\
(TBR Library Deans and Directors Group) - Tennessee \\
LOUIS (The Louisiana Library Network) - Louisiana \\
MOBIUS - Missouri \\
NILRC (Network of Illinois Learning Resources in Community \\
\hline
\end{tabular}




\section{U.S. Academic Library Consortia: A Review}

\section{Colleges)* - Illinois}

Orbis Cascade Alliance - Oregon/Washington

SUNYConnect (State University of New York) - New York

VALE (Virtual Academic Library Environment of New Jersey) New Jersey

WALDO (Westchester Academic Library Directors Organization)

- New York

WISPALS Library Consortium (Wisconsin Project for Automated Libraries)* - Wisconsin

Wyoming Community College Library Consortium* - Wyoming

*Two-year consortia.

\section{Part I: Consortial Beginnings}

The oldest consortium reviewed for this project originated in the 1970s; more than half of the organizations began in the 1990s. Consortia fall into two groups based on the impetus behind their formation: (1) those created primarily for the purpose of a joint catalog or shared integrated library system (WALDO (1983), WISPALS (1989), LOUIS (1992), Orbis Cascade Alliance (1993), SUNYConnect (1998), and MOBIUS (1998)) ; and (2) those created primarily to leverage purchasing power for electronic resources and other library services (NILRC (1973), RLDC (1996), the CCLC (1998), VALE (1998), the Carolina Consortium (2004), and the Wyoming Community College Library Consortium (2006)). The origins of some consortia are more complex. CARLI (2005) belongs in both categories because it was formed by the merger of three consortia, including one that licensed electronic resources and another that administered a shared integrated library system. The ICCOC (1999) is unique in that it is not a library consortium as such but rather a consortium for online education with a library resources component. The Tennessee Board of Regents Library Deans and Directors Group (mid-1980s) formed as a vehicle for library administrators to communicate and collaborate on a number of shared issues. The group evolved to the point of licensing a few electronic resources, but this is 


\section{U.S. Academic Library Consortia: A Review}

still not its major goal or mission even though issues regarding electronic resources are often discussed.

Many interviewees credited the vision or efforts of an individual or small group as being instrumental in the creation or progress of their consortium. For the Wyoming Community College Library Consortium, a state legislator with determination to support community colleges was key to its foundation. At WISPALS, librarians from three technical colleges demonstrated their resolve to create a shared system. The idea for VALE was initiated through the efforts of ten library and information technology leaders. William Paterson University, one of the colleges originally involved, still acts as VALE's fiscal agent. Community college involvement in SUNYConnect resulted when two library directors protested their schools' exclusion from the Library Automation Implementation Program, SUNYConnect's predecessor, in 1987. Southeastern Community College's (SECC) president is credited with spearheading the ICCOC, and the SECC librarian initiated the consortium's online library presence. SECC also continues to be ICCOC's fiscal agent - another testament to the commitment of one college. Carolyn Hargrave, the former vice chancellor from Louisiana State University, was singled out for her tireless efforts in the implementation of LOUIS. Tim Bucknall founded and still serves as the convener of the Carolina Consortium. Finally, Orbis Cascade Alliance Executive Director John Helmer continues to be instrumental in promoting and expanding consortial services in Washington, Oregon, and Idaho.

\section{Part II: Consortia Membership Structure}

There are few absolutes to be found when examining consortia membership and membership structures, even when all of the consortia are academic, as in the present study. 


\section{U.S. Academic Library Consortia: A Review}

Of the 15 consortia, 6 (CARLI, NILRC, Orbis Cascade Alliance, RLDC, WALDO, and WISPALS) offer multiple membership levels. Of these 6 consortia, 4 (CARLI, Orbis Cascade Alliance, WALDO, and WISPALS) have an integrated library systems component or option.

As previously stated, CARLI was created in 2005 from three existing Illinois consortia. One of these administered a shared integrated library system and contributed about one-half of the current CARLI members. Membership levels are determined by annual membership fees paid by the individual college regardless of institution type (two-year or four-year). The Governing Membership category, which includes a vote in the consortium governance, requires an annual fee determined by student FTE and institution type. Fees run from $\$ 1,000$ to a maximum of $\$ 10,000$. An Associate Membership, available for a flat rate of $\$ 500$, allows a college to participate in the governance as part of a group. Basic Membership, available for $\$ 100$ annually, allows eligibility for specific services but no participation in governance. CARLI's membership levels are well defined and offer specific roles within the governance structure of the consortium.

The Orbis Cascade Alliance began as a system-based consortium with the mission of providing a shared catalog to its members. Technological changes and the development of OCLC Navigator have allowed the Alliance to change its Full Members category. The same system is no longer needed. Instead, a system compatible with OCLC Navigator and the library's holdings in the shared catalog are now required for Full Member status. Full members are also expected to participate in the courier service, electronic resources acquisitions, and the governance of the consortium through a vote on the Alliance Council. Membership dues are set with all colleges paying the same rate for $40 \%$ of the budget and a rate based on FTE for the 


\section{U.S. Academic Library Consortia: A Review}

remaining $60 \%$. The Alliance's distinctive FTE calculation allows for a general reduction in fees for two-year colleges. The Alliance also has Program Members, who take part in selected initiatives such as the Northwest Digital Archives; and Contracted Services Members, who can take advantage of specific offerings such as electronic resources and the courier service. These membership levels enable some public libraries to participate in the Alliance. Program and Contracted Services Members do not participate in the Alliance governance.

Full Membership in WALDO requires institutional buy-in to the shared integrated library system, contribution of records to the union catalog, and participation in reciprocal borrowing and interlibrary loan. Each Full Member organization has two votes. Associate Members are not required to participate in the integrated library system and have one vote. Limited Membership is reserved for institutions that contract for electronic resources and services; these member institutions are ineligible to vote. Membership fees are currently based on a flat rate, with Full Members paying substantially more. Because of technological changes and open source library systems, WALDO plans to review its membership levels in the near future, and changes are anticipated. WALDO does not generally have active voting by its membership but a membership vote is required for any structural changes.

WISPALS, a system-based consortium for two-year technical colleges in Wisconsin, has 11 current members. Ten of these colleges are Full Members, who participate in the integrated library system, contribute to consortial staff salary, and have access to e-reserves software and electronic resources. Each Full Member institution is a voting member of the governing body. Participating Members contract only with e-reserves software and electronic databases, and while eligible for representation on the Consortium Board, have no voting rights. A Cooperative 


\section{U.S. Academic Library Consortia: A Review}

Purchasing Member category was recently created to broaden the appeal for institutions who wish to participate in electronic resource purchases. This new category currently has no members but demonstrates that even a seemingly restrictive consortium (two-year colleges and system-based) has multiple member categories to appeal to a wider variety of institutions. WISPALS has no membership fees; however, staff wages and the integrated library system charges are equally distributed among the 10 Full Members.

RLDC and NILRC began as resources- and services-based consortia and do not have an integrated system/shared catalog requirement or option. NILRC preserves its original focus in that only two-year colleges may be Full Members with voting privileges and higher dues (currently \$900 per year). However, like WISPALS, NILRC has added an Associate Member category ( $\$ 400$ annually plus $\$ 100$ per database) to broaden its electronic resource participation. Current Associate Members include two universities, a for-profit college, and some two-year colleges in the state of Missouri. Although NILRC began as an Illinois consortium, its bylaws allow two-year colleges from bordering states to be eligible for Full Membership.

RLDC currently has two membership categories, Full and Affiliate. Full members were required to participate in a core database purchase that merged with and became part of a statewide database package; this requirement was removed in early 2009. Additionally, Full members are responsible for the salary of a part-time coordinator who assists in electronic resource purchases. Full members include 10 two-year colleges and 8 four-year colleges and universities. Affiliate members participate in electronic resource purchases but do not contribute to the coordinator's salary. There are no structured membership fees. RLDC's 


\section{U.S. Academic Library Consortia: A Review}

membership levels have little to do with its governance - a divergence from the practices of CARLI, NILRC, Orbis Cascade Alliance, MOBIUS, VALE, WALDO and WISPALS. However, RLDC has no bylaws and has never officially been recognized as an entity within the higher education administration of Kansas. Although there is no voting structure per se, issues such as acknowledgments of past chairs are sometimes put to informal votes by whoever is present at a meeting.

Of the nine consortia with no professed membership levels (Carolina Consortium, CCLC, ICCOC, LOUIS, MOBIUS, SUNYConnect, TBR Library Deans and Directors Group, VALE, and the Wyoming Community College Consortium), seven were developed through statewide initiatives with state funding or attached grants. Although at least two of these consortia no longer receive state funding, the tie to a state government or entity is still strong. Two of the consortia were not developed by statewide initiatives. The Carolina Consortium is an open virtual consortium for the purpose of purchasing electronic resources. It has an informal structure; one individual volunteers as liaison, and there are no membership fees or voting memberships. The TBR Library Deans and Directors group is based on collaboration and communication, not for the specific purpose of purchasing resources or maintaining systems. There are no membership fees; however, issues such as bylaw changes and recommendations to the Office of Academic Affairs may be brought to a vote, with each institution having one vote regardless of institution type.

Although these nine consortia have no defined membership levels, many have developed partnerships with other organizations and libraries, offering a membership fee structure and voting privileges. MOBIUS developed a Cooperative Partnering status because 


\section{U.S. Academic Library Consortia: A Review}

two public library systems who share the same integrated library system wished to partner in the lending and borrowing service the consortium administers. Although not officially a different membership level, it is an opportunity that MOBIUS has taken to expand its services and partners. Recently, MOBIUS approved Cooperating Partners as voting members of its Council. MOBIUS uses membership and assessment fees to pay for core services such as system server administration and help desk. Membership fees currently run $\$ 10,000$ for each institution, regardless of institution type. MOBIUS libraries also pay an assessment fee that is calculated using a number of factors such as items owned and loaning and borrowing statistics in order to address equity of payment issues. Cooperating Partners do not pay membership fees because they run their own servers, but they do pay assessment fees. All participating institutions are considered members, and each has an equal vote on the MOBIUS Council.

The CCLC in California has participants rather than members. Participants are generally defined as colleges with permission from vendors to purchase the electronic resources that CCLC offers. This definition includes not only the 112 community college libraries in California but some community colleges in Arizona and, in the case of one product, Texas, and Oregon. However, only representatives from California colleges serve on the Council of Chief Librarians that oversees the CCLC. Colleges pay an annual fee of $\$ 125$ for membership in the Council of Chief Librarians.

LOUIS membership is defined by the State of Louisiana and historically included only public academic colleges. Because of the consortium's expansion into digital projects and software, museums and archives with state relationships have now become members as well. Members of LOUIS may vote on issues regarding electronic resources after they are presented 


\section{U.S. Academic Library Consortia: A Review}

by a recommendation committee. Although the consortium has no membership levels, membership fees vary depending on the services received and the institution's student FTE. The state's Board of Regents funds two-thirds of LOUIS's budget in the form of a grant, and members pay the remainder with fees based on services and FTE. There are no formal contracts between LOUIS and its members and no member requirements including participation in the integrated library system.

ICCOC has no membership fees, but each participating college is considered a member and has one vote (generally cast by the chief academic officer) in deciding issues such as setting tuition for online courses and the consortium budget used for funding staff, a help desk, professional development events, and library electronic resources. ICCOC is funded through a portion of tuition payments and also recently completed a Title III Grant funding cycle.

SUNYConnect has fees associated with its integrated library system and charges

additional fees for databases. Recently SUNYConnect conducted a full revision of its financial plan and introduced the concept of core services (that everyone pays for) and optional services (that members choose to buy into). The consortium's full membership, which includes SUNY colleges, does not vote as a body but instead votes through a Council elected from within the membership. Statewide funds pay for $35 \%$ of the consortium's costs, with the other $65 \%$ paid by campuses.

The VALE Members' Council is made up of the chief library administrator from each institution, and each representative has one vote regardless of institution type. Members vote on issues such as policy, bylaw changes, and the consortium operating budget. Database 


\section{U.S. Academic Library Consortia: A Review}

invoices to members include a service fee calculated as a small percentage of the individual library's previous year database expenditures. There are no membership fees.

The Wyoming Community College Consortium also has no membership fees: funding for electronic resources is provided by the state. There are seven member colleges, each represented by the library director. These member representatives vote on which electronic resources to purchase; if there are four or more "yes" votes, the resource is acquired.

As seen in this brief survey, consortia membership can take many different forms based on the organization's foundational structure and developing mission. As consortia expand and evolve, governing bodies are finding it valuable to review and redefine membership levels and roles. The availability of a variety of membership levels may help to expand a consortium's appeal and attract new members. During the review of membership levels and structure, the interconnectedness of governance and membership became evident.

\section{PART III: Consortial Governance Structure}

The ways in which consortia are governed reflect the variety of membership roles and missions in these organizations. Most consortia have at least one part-time staff member; these employees tend to focus on day-to-day operations while coordinating their efforts closely with member representatives. The majority of governance is relegated to consortia members, who volunteer extensive time and talent to assist in consortia administration.

Only three of the 15 surveyed consortia (Carolina Consortium, TBR Library Deans and Directors Group, and the Wyoming Community College Library Consortium) do not have a paid staff position. The Carolina Consortium has no board or governing body; one individual from a 


\section{U.S. Academic Library Consortia: A Review}

participating institution voluntarily coordinates electronic resource purchases, spending approximately $20 \%$ of his time to do so. Recently the same university has hired a second person to assist with consortial electronic resource coordination. The Carolina Consortium holds an annual meeting to discuss possible new resources. Two campuses alternately host this meeting and absorb the cost. Current participants seem satisfied with this informal arrangement.

The TBR Library Deans and Directors Group is an officially recognized Campus Liaison Group that reports to the Office of Academic Affairs of the Tennessee Board of Regents. This group meets chiefly for collaboration, deliberation, and discussion of joint issues and is not focused on provision of services. However, when decisions are needed, each institution has an equal vote regardless of institution type.

The Wyoming Community College Consortium, the newest consortium in this review, has no paid staff. The library directors of the seven member community colleges serve on a committee that decides how to expend the state-supplied electronic resource funding. One member will voluntarily coordinate a new purchase and present the information to the entire committee for a vote. This committee reports to the Wyoming Community College Commission, which then reports to the college presidents.

Of the 12 consortia with at least one staff member, most still depend on membership or oversight bodies for consortial governance and administration. CARLI has a sizeable staff that is involved in the many day-to-day operational and technical processes of the consortium but which is not directly involved with governance. Although each institution holding a Governing Membership has an equal vote regarding changes in policies and bylaws, the CARLI Board of 


\section{U.S. Academic Library Consortia: A Review}

Directors tends to the general governance of the consortium including setting strategic direction and oversight of committees and budget. This 13-member board is elected by the Governing and Associate Members and meets regularly. Its structure includes representatives from public universities, community colleges, and private institutions (three each) as well as three members elected at large by the Governing Members. A thirteenth member is elected by the Associate Members to serve as their representative. There are also three ex officio nonvoting members; these include the CARLI Executive Director, a representative appointed by the Illinois Board of Higher Education, and a representative from the Illinois State Library. The Board reports to the Membership. CARLI is also a unit of the University of Illinois University Office for Academic Affairs, and therefore, the executive director has a dual reporting responsibility to both the Board and the University.

The Community College Library Consortium of California (CCLC) is a partnership between the Community College League of California and the Council of Chief Librarians (CCL). The governing body is the Council of Chief Librarians. The CCLC has a full-time consortium director who coordinates electronic resources and a 0.75 FTE clerical staff person who works with invoices and billing. A standing committee within the Council of Chief Librarians is the Electronic Access \& Resources Committee (CCL-EAR), which draws its representation from the 10 community college districts and whose purpose is to determine what products are offered through the consortium. Appointments to the CC-EAR are made through the Council of Chief Librarians Executive Board. Until recently, the state of California provided $\$ 36,000$ to each community college for the purchase of electronic resources; however, this funding has now been eliminated. 


\section{U.S. Academic Library Consortia: A Review}

The ICCOC has a staff of 10 (7.0 FTE) including an executive director who, unlike most of the consortia interviewed, take a major role in setting strategic direction and other governance functions. Because the ICCOC focuses on online courses, faculty, and training, there is no staff that coordinates library electronic resources even though these are purchased as part of consortial services. Instead, one library director from a member college takes on the role of lead librarian and acts as liaison between the librarians and consortium to determine which electronic resources to purchase. The consortium reports to an oversight committee made up of chief academic officers and deans and directors of distance learning. In addition, consortium meeting summaries are forwarded to the college presidents.

The executive director and staff of LOUIS also take a leading role in administrative oversight and strategic direction-setting for this consortium. A governing board, the LOUIS Library Network Commission (LLN), meets infrequently and reports to Academic Affairs within the State Board of Regents. The LLN is made up of the Deputy Commissioner or Associate Commissioner of Higher Education for Academic Affairs of the Board of Regents (who serves as chair); the head of the LSU Office of Computing Services; the Dean of LSU Libraries; a representative of the Chief Academic Officers; and three LOUIS members, nominated from the Executive Committee of the Louisiana Library Information Network Consortium (LALINC) as they rotate off from that committee. The LOUIS network director is an ex officio member. Although institution type does not play a role on who is on the Commission, two-year colleges are encouraged to participate on the LALINC Executive Committee and may then, depending on their role, rotate onto the Commission through election. LALINC is an entity separate from 


\section{U.S. Academic Library Consortia: A Review}

LOUIS but, through an informal relationship, makes recommendations to LOUIS through their

Executive Committee members (who may then serve on the LLN Commission).

MOBIUS, using a structure similar to that of CARLI, is governed by the MOBIUS Council.

This council is made up of the library dean or director of each member institution; and the MOBIUS Executive Committee, which is made up of officers and members elected from the Council. There are additional ex officio non-voting members on the Council from the Missouri Coordinating Board for Higher Education and MOREnet. Council officers serve on the Executive Committee, and four at-large members are elected by the Council. Two at-large members represent independent institutions, and one each represents four- and two-year public institutions. The Executive Committee meets regularly and, like CARLI, is responsible for the operational governance of the consortium. The MOBIUS staff and Executive Director work on day-to-day operations and carry out the direction of the Council. Again similar to CARLI, MOBIUS is linked with a large university. MOBIUS staff are University of Missouri employees, and the Executive Director reports to the Vice President of Information Technology as well as the Council. However, unlike CARLI, MOBIUS receives no money from the university or state and must reimburse the university for office space and equipment use.

NILRC is a $501(c)(3)$ non-profit organization. It has a staff of two that carries out day-today operations and is governed by a Council of Delegates made up of representatives from each of the two-year full member institutions. Each institution determines who its delegate will be. NILRC also has an Executive Committee, made up of eight delegates elected from the Council, and an Executive Director. The Executive Committee and Director move issues forward and provide continuity between Council meetings. 


\section{U.S. Academic Library Consortia: A Review}

The Orbis Cascade Alliance is governed by a Council made up of the 36 library directors from each member institution. Each Council member has an equal vote regardless of institution type. A seven-member Executive Council is selected from the Council with no specific distribution or representation requirement. As members rotate off the Executive Council, nominations are sought from any Council member who is willing to serve and with the time to devote to the Executive Council's extensive demands. Similar to MOBIUS and CARLI, and most likely a function of consortium size, the Alliance's Executive Council tackles most of the operational governance of the consortium, with the full Council voting on policy changes and bylaws. Also similar to MOBIUS and CARLI, the eight Alliance staff members and Executive Director are considered employees of the flagship university, the University of Oregon.

Since 1999, RLDC has consisted of representatives from both four- and two-year Kansas Board of Regents (KBOR) colleges and universities but, until recently, only members from fouryear colleges were eligible to act as RLDC Chair. In 2009 RLDC instituted a revised structure led by two co-chairs, one each from a four-year and a two-year college. RLDC also recently created an Executive Committee consisting of the two co-chairs, past and incoming chairs, the RLDC Coordinator (staff), an affiliate representative, and one at-large appointee. When it first began in 1998, RLDC consisted of only four-year colleges and universities, and the membership still reports to the Council of Deans and Directors of Libraries (CODDL), which includes only representatives of four-year KBOR colleges and universities. Although it reports to the Council of Chief Academic Officers (COCAO), an officially recognized council at KBOR, CODDL is not an officially recognized KBOR subgroup; this may explain why RLDC has remained an unofficial and 
unrecognized consortium. RLDC has no bylaws and no official mission, although it maintains a main goal and procedures on its Web site.

RLDC has a 0.5 FTE coordinator who also serves part-time as an employee of the University of Kansas. Although there was recent discussion about eliminating this position, most RLDC participants agreed that the need for a coordinator was substantial. Therefore, the University of Kansas agreed to maintain the position for the 2010 fiscal year only with consortium members sharing the cost. In a recent document entitled "Towards a Better Kansas Library Consortium", CODDL members proposed a new consortium structure in which: "... the Kansas Board of Regents (KBOR) recognize a system-wide library consortium as the authorized entity to collaboratively acquire, organize, preserve and expand access to information resources for the Kansas academic community. This consortium shall be comprised of CODDL, Kan-Ed and the KBOR Vice-President for Academic Affairs." That a structure and governance change would be proposed with no two-year college collaboration or representation is unique among the project participants and may underscore CODDL's historical reluctance to share consortial governance with two-year colleges.

SUNYConnect operates as an office within the Library and Information Services Division of the SUNY Office of the Provost with staff members who are SUNY employees. The SUNYConnect Advisory Council (SAC) acts as an advisory board for the Office of the Provost and effectively administers the consortium by coordinating its services and making recommendations regarding technology implementation. The Council is elected from among library directors from the SUNY campuses, with a defined structure of two representatives from doctoral institutions and one each from a four-year college, community college, and college of 


\section{U.S. Academic Library Consortia: A Review}

technology. Other SUNY constituencies, including the Council of Chief Information Officers and Chief Academic Officers, are also represented on the Council.

The VALE Members' Council consists of the library director or chief library administrator from each of its member institutions. From this Council, representatives are elected to the Executive Committee in a structured representation model. There are two representatives from state colleges and universities, three representatives from community colleges, and two representatives from private institutions. Additionally, the three research institutions in New Jersey are ex officio members. Other representatives of the Executive Committee include the Chair of the Members' Council; NJLA Executive Director; a New Jersey State Library Representative; and the Library Director of VALE's fiscal agent, William Paterson University. The Executive Committee has the responsibility for general oversight of consortium operations and makes recommendations to the Members' Council as needed. The VALE Executive Committee reports to the Members' Council, and the Members' Council reports to the Presidents' Council of the Commission on Higher Education. VALE has two part-time staff members; the Coordinator (.6 FTE) and a systems staff person (.15 FTE).

WALDO, like NILRC, is a 501(c)(3) non-profit organization. The governing body of WALDO is an 11-member Executive Board consisting of Full and Associate Members. WALDO staff members serve on the board but do not vote. The Executive Board is made up of four officers, the immediate past president, three elected Full Members, and three elected Associate Members. WALDO employs weighted voting so that Full Members have two votes each and Associate Members, one each. This applies to the Executive Board as well as the infrequent general membership voting needed for organization structure changes. 


\section{U.S. Academic Library Consortia: A Review}

The governing body for WISPALS is an Executive Committee consisting of the library director for each institution or his/her designee. Each of the Full Members has voting rights, whereas the one Participating Member does not. The Executive Committee reports to a Consortium Board made up of the college presidents or designees. Although the Consortium Board controls financing, it tends to act in an advisory and approval role, with the Executive Committee setting direction and policy. WISPALS has two staff members who work with the system server and electronic resource coordination.

Nine of the 15 consortia (CARLI, CCLC, MOBIUS, NILRC, Orbis Cascade, RLDC, SUNYConnect, VALE, and WALDO) have smaller subgroups, representative of the larger membership body, that take the form of executive committees or councils. These subgroups often play a major role in consortium administration, set strategic directions, and make recommendations to larger membership bodies. This makes a great deal of sense if the consortium has a large number of schools or is a multi-institution type consortium. For small consortia with a limited number of schools (e.g., WISPALS, the Wyoming Community College Consortium), having full membership represented in all decisions may be more practical. Less often, as in the case of ICCOLC and LOUIS, consortium staff members are placed in more governing or administrative roles but report to other oversight bodies or entities. Finally, several of the consortia representatives noted that a review and analysis of organizational structure, membership, and governance were planned in the near future and four consortia are reviewing the possibility of shifting to $501(\mathrm{c})(3)$ non-profit status.

\section{PART IV: Electronic Resources and Fiscal Agency}




\section{U.S. Academic Library Consortia: A Review}

Inclusion in this project required that consortia offer electronic resources purchasing services for members. Only two consortia (ICCOC and Wyoming) fully fund electronic resources for their members, and three others (CARLI, LOUIS, and SUNYConnect) fund some resources for their members through grants or state funding. Most consortia purchase electronic resources as a service to members but do not fund the purchases. All of the consortia provide a combination of negotiation, licensing, and billing services that varies with staffing levels and governance structure.

Most consortia depend on vendor pricing rather than consortia-developed formulas to determine the cost for each member institution. Vendor pricing is commonly set using student FTE figures. One consortium representative observed that it is a vendor's business to know its products and market; vendors therefore should be able to set reasonable pricing without the consortium having to intervene. RLDC outlines its pricing formula in its procedures manual (generally based one-third on usage, one-third on acquisitions budget, and one-third on FTE) but rarely applies it because of a problem with larger schools paying more than what they would pay if they negotiated for the product on their own. The Orbis Cascade Alliance often uses a combination of a flat rate percentage, FTE, and materials budget (e.g., $50 \%$ distributed equally, $25 \%$ based on FTE, and $25 \%$ based on materials budget). WALDO employs maximum and minimum caps to address pricing issues when necessary, although weighting factors are not used in determining cost. SUNYConnect uses a formula of one times FTE for four-year colleges and .5 times FTE for two-year colleges to recover costs not covered by the state subsidy; for its integrated library system expenditures, SUNYConnect uses library staff FTE to determine cost. 


\section{U.S. Academic Library Consortia: A Review}

Several vendor pricing models were described as unpopular by those interviewed.

These include pricing models that are volume based (i.e., where a certain number of

institutions or the entire group must participate). In addition, consortia members dislike usage based pricing (which is thought to be a disincentive to use the product) and any package extended only to new participants. Finally, consortia staff find packages based on total dollar amounts less workable if members need to drop out of the purchase for any reason. One interviewee said that her consortium's desired model was a tiered model (e.g., 0-1500 FTE), with an additional discount level based on participation. This is not the same as a volumebased pricing model because a discount is applied in addition to the discounted pricing set by tiers. Another consortium's preference was the FTE model. Most interviewees said that they have worked with nearly all types of pricing models offered by the vendors in an attempt to provide the best possible service to their members.

Although many consortia do not apply surcharges or administrative fees to their electronic resource services, others apply surcharges in varying degrees. Two consortia apply surcharges for all of their resources to pay for overhead such as staff salaries, benefits and Web site maintenance. Surcharges for one consortium range from 3-6\%; the other charges $5 \%$ for databases but up to $12 \%$ for supplies ordered through the consortium. The latter consortium also charges its associate members a fee on top of the surcharges but caps the total amount that associate members pay for their membership and fees. Another consortium has a standard $5 \%$ administrative fee that applies to all membership levels but is not added for all purchases. Yet another consortium applies service fees based on level of membership, with no charges assigned for full members. One consortium recently contracted with another campus 


\section{U.S. Academic Library Consortia: A Review}

office allowed to charge up to $3 \%$ of the cost of the database; another consortium is discussing the possibility of applying surcharges of $1-5 \%$ but has not yet done so. Many consortia cooperate or partner with larger regional consortia for specific resources, and surcharges are always included for those products. For those consortia who do not apply surcharges, annual membership or consortia service fees often act as overall administrative charges for services provided.

Electronic resource pricing for two-year colleges is commonly discounted from that of four-year institutions regardless of FTE; this is because of how databases are used and the significantly lower acquisitions budgets at two-year colleges. Nearly all consortia interviewees from both two- and four-year institutions noted that vendors often discount two-year colleges by $50 \%$ or take $50 \%$ of FTE for pricing purposes. One exception is RLDC, which has not traditionally applied discounts for two-year colleges when applying its formula other than taking into account the acquisitions budget. As consortia utilize vendor pricing, discounts are likely to be vendor-driven.

In general, colleges and universities pay for electronic resources procured through a consortium either by paying the vendor directly; or by paying the consortium, which then issues one payment to the vendor for all of its participating members. In the second instance, the consortium is using itself or a partner to act as a fiduciary or fiscal agent for its membership. There is a common assumption amongst libraries that those consortia who utilize fiscal agents get the best pricing and steepest discounts for its membership. Twelve of the 15 consortia interviewed, have designated fiscal agents, with seven institutions (CARLI, ICCOC, LOUIS, MOBIUS, Orbis Cascade Alliance, VALE, and WISPALS) using specific colleges or universities as 


\section{U.S. Academic Library Consortia: A Review}

their fiscal agents. Two consortia (NILRC and WALDO) are 501(c)(3) non-profit organizations and act as their own fiscal agent, and three others (CCLC, SUNYConnect, and the Wyoming Community College Consortia) use a higher state entity. Both the TBR Library Deans and Director's Group and RLDC use large, multi-type regional consortia to act as fiscal agents even though they are not officially designated as such. The TBR Library Deans and Director's Group pays for one resource through its Board of Regents; however, the Board of Regents is reluctant to be responsible for multiple resources. The Carolina Consortium does not have a fiscal agent, and all vendors must agree to invoice the institutions individually. RLDC also requests vendors to bill participants individually as needed. Vendors must have a New York state contract if they wish to invoice SUNYConnect; otherwise, vendors must bill SUNYConnect colleges individually. Although two-thirds of the academic consortia interviewed use a university or state agency as a fiscal agent, identifying the cost of this service is difficult. These figures are often buried in operational expenses, and a cost analysis of fiscal agency is rarely undertaken. Several consortia pay expenses back to their fiscal agent for office space, server maintenance, telephones, and staff. Total operational expenses can run from 2-10\% of a consortium's expenditures, and an annual average of $\$ 100,000$ for staff and services was calculated from four consortia that provided operational budget figures. This figure includes all consortial services, so fiscal agency expenses would constitute only a portion of that amount.

Other universities, colleges, and state entities do not charge the consortium for operational services, instead absorbing the costs of doing business either because the consortium is seen as a department within the university or because a particular college was instrumental in the consortium's development and has a strong philosophical commitment to 


\section{U.S. Academic Library Consortia: A Review}

its consortial role. William Paterson University, VALE's fiscal agent, Gateway Technical College for WISPALS, University of Illinois for CARLI, Southeastern Community College for ICCOC, the Community College League for CCLC, The Wyoming Community College Commission for the Wyoming Community College Consortium, and the SUNY administration are all examples of entities who generally absorb the cost of fiscal agency because of a mission or dedication to the consortium's services.

Several individuals interviewed noted that purchasing electronic resources (e.g., negotiations, coordinating member participation, licensing, invoicing and collection of monies from member institutions) is an exceptionally time-intensive task, but most feel that the value their membership receives through the best pricing for resources is well worth the effort.

\section{Part V: Positive Attributes}

Consortia representatives were asked to describe the best traits of their consortia or what aspects of their consortia worked particularly well. Not surprisingly, many noted their consortium's ability to leverage the size or numbers of members to reduce prices for electronic resources and systems. One interviewee said that because of their weight in numbers and purchasing power, her consortium was able to impact vendor decisions such as displaying advertisements in databases. Other consortia representatives observed how their purchasing power helped to substantially reduce the cost for their members and save millions of dollars for these institutions.

Above and beyond buying power, interviewees observed how their consortia successfully brought together librarians to collaborate, cooperate, and communicate with each other. Many noted a strong sense of community and commitment that allowed their consortia 


\section{U.S. Academic Library Consortia: A Review}

to remain active and vital. Within multi-institution consortia, several interviewees remarked about the collaboration between two- and four-year colleges and universities, and emphasized the value accorded to the voice of their two-year colleagues. Some consortial efforts such as the Wyoming Community College Consortium and SUNYConnect have been held up throughout their states as frameworks for conducting business in a collaborative and cooperative manner. One consortium's members conduct extensive product reviews that are instrumental in helping libraries make purchasing decisions. This is just one example of active membership noted by interviewees.

Another best trait mentioned was the professional development components such as training or conferences offered by several consortia (e.g., MOBIUS, LOUIS, and VALE). The LOUIS representative specifically cited as a consortium strength the expertise of its members who help train other members. The annual conference hosted by VALE provides a rare opportunity for academic librarians to gather from around the state, and during an analysis of VALE's services, received some of the highest-rated feedback.

Consortia staff members were mentioned several times as a positive attribute. One interviewee specifically noted that the consortium Help Desk was excellent, providing good customer service, while at least two mentioned the value that their executive directors bring through project management and leadership. One executive director described his staff members as "stars", and a consortium coordinator for electronic resources suggested that the coordinator role could provide an effective conduit for members when there are problems or issues with vendors. Vendor negotiations, consolidated invoicing, and licensing services are just 


\section{U.S. Academic Library Consortia: A Review}

some of the valuable traits mentioned as the interviewees spoke about the services they provide that work well in their consortia.

Another interesting trait observed by representatives from both large and small organizations was their consortium's flexibility in addressing the needs and concerns of its members. As interviewees discussed positive traits within their consortia, the pride in collaboration and service was evident.

\section{Part VI: Challenges and Goals}

Aside from their numerous positive traits and features, consortia face a wide range of challenges, not the least of which is funding. Twelve consortia representatives mentioned money or budget as a significant challenge. As state budgets tighten and individual member libraries lose funding and withdraw from electronic resource packages, academic consortia are faced with financial dilemmas. Relationships that some consortia have forged with state entities become liabilities as budgets and funding are slashed, leaving few alternatives. Budgets have been so drastically cut in some states that the top goal cited by one consortium is survival, and another has ceased submitting requests for state funding even though still legally tied to a state entity. However, as one consortium representative noted, although money is always a challenge, they do not operate under the fear of that. Instead, if a service will be beneficial to its members, the consortium will find a way to provide it.

A shrinking budget pool may be one factor, although not the only one, causing four consortia to explore the possibility of cutting ties with their state agency and becoming 501(c)(3) non-profit organizations. These consortia are currently in the midst of some extensive restructuring analysis and review. Five other consortia, some that already have 501 (c)(3) non- 


\section{U.S. Academic Library Consortia: A Review}

profit status and others with no plans to change legal status, also identify organizational structure or governance challenges within their consortia. Others link their future goals to working on these challenges and recognize that part of their structure will need to change to keep their consortium viable in the coming years.

Several representatives mentioned membership issues as challenge areas for their consortia. In one case, technological change continues to drive the direction of how membership will be defined. In another, retiring deans and directors are challenging the consortium to address new administrators' understanding of problems and issues that the consortium manages. Still another cited the problem of merging different membership groups into a new structure, and three interviewees mentioned the challenge of helping their members move forward in the face of rapid technological changes, shifting landscapes of information delivery, and changing strategic priorities.

Other challenges center on the provision of electronic resources. Although providing electronic resources and leveraging purchasing power are seen as major services by most academic consortia, there are considerable uncertainties associated with this benefit, including continued funding using state funds or federal grants. Two consortia that include both twoand four-year colleges and universities mentioned that it is difficult to find resources that meet the needs of both institution types; others mentioned the significant time element that electronic resource negotiations and coordination demand. One representative noted that, at some point, the time spent on coordination may exceed the relatively small amount of money saved. Vendors can also pose challenges for consortia. One interviewee stated that he spends more time negotiating with vendors than on members' needs. Another felt that vendors lacked 


\section{U.S. Academic Library Consortia: A Review}

standards and organization in how they approached electronic resource pricing. Yet another noted the challenges of encouraging vendors to realistically adjust their pricing expectations.

Although most consortia participants and staff are pleased with collaboration efforts, some representatives feel that the ability to come to a consensus, get things accomplished, and communicate are still significant challenges in their organizations. Additionally, one interviewee noted challenges regarding two-year institutions: namely, the perceived difference in the mission of institution types and the subsequent difficulty in extending full benefits to the two-year college members. Another representative noted a new challenge: addressing services to for-profit institutions, particularly now that traditionally non-profit colleges are branching out into profit-making enterprises. One interviewee mentioned the need to update its informational database which was not designed for the sophisticated pricing that vendors now offer.

Another interviewee cited the issue of empowerment as a challenge. This may come about when consortia that share systems and a central administration relinquish flexibility and independence for security. Finally, two interviewees discussed the challenge of working with other consortia. Consortia may find themselves in competition with other statewide or regional groups, thus making it more difficult to offer the best prices for their members. Many consortia are seeking to cooperate with other consortia in new ways that will bring the best benefits to their members. As one consortium representative said, the bottom line is to provide libraries with options.

When interviewees were asked to state their future goals, many linked these with the challenge of funding. One consortium's goal is simply survival; another's is just to maintain the 


\section{U.S. Academic Library Consortia: A Review}

status quo, with all of their electronic resource deals intact and participants continuing to receive current resource packages. Others spoke about their plans for organizational restructuring, and three consortia pointed to specific documentation on their organization's Web site regarding strategic priorities and future goals. Several consortia concluded that their goal was to continue providing service to academic libraries, continue cost savings for their members, and identify new services or resources that will help libraries save time. Cooperative shared models continue to be a prominent theme for consortia.

\section{Conclusion}

During the interviews with consortia representatives, several effective practices or characteristics emerged that may strengthen academic library consortia. How a consortium manages its membership levels is one critical feature. Many of the consortia interviewed have more than one membership level, and several have multiple well-defined levels that make the consortium attractive to a variety of institution types and budgets. As academic library consortia look to the future, expanding membership to be as inclusive as possible is a good way to allow the consortium to grow and remain vital. There may be situations that require consortium membership to be limited because of funding or mission. However, providing multiple, distinct, and comprehensive membership levels may help academic library consortia grow and survive in tough economic environments.

Membership is often closely tied to a consortium's governance structure, another critical feature of consortia. Allowing members a voice in governance strengthens a consortium because it creates stakeholders. Consortia with weak or absent governance structures may be more flexible in some situations, but they also may often depend on one individual to drive the 
consortium's purpose. How a governing membership ties into the consortium staff, as well as the oversight board or body, are important issues that must be addressed and reviewed by the membership as it works within its governance structure. A well-defined governing structure that takes into account the voice of its members may help with the communication issues voiced by some consortia representatives.

Several consortia, particularly those with a systems-based component, noted the rapid change of technology and how it affects the services they currently or may potentially offer. Some interviewees spoke about the need to assist their member libraries with options like federated searching, discovery layers, and open source systems. However, consortia can be hampered in providing this assistance due to limited staff. Even electronic resources and the technology related to these services are changing as e-book and streaming video packages proliferate. Consortia members must examine and make decisions about which new technologies are appropriate for and helpful to their members. As new technologies are offered or promoted, old technologies, including old system structures, may need to be retired. Other consortial services must be reviewed and discarded as they lose value, or consortia staff may find themselves spending limited and precious time on services no longer used by the majority of their members. With consortia staff constrained, the membership must be willing to take a role in the evaluation of both technology- and non-technology-based consortial services.

Fiscal agency may still play an important role in obtaining the greatest savings for electronic resource services in consortia. Although most consortia have access to member savings and cost avoidance figures, little information was available from those interviewed as to 


\section{U.S. Academic Library Consortia: A Review}

the actual costs of fiscal agency. In some cases, the fiscal agent is a volunteer institution, but this arrangement may be precarious in a difficult economy or as those administrators initially involved in the agreement retire or move to different institutions. The fiscal agency relationship is an important factor for those consortia currently considering the legal change to 501(c)(3) non-profit status. A consortium may find it valuable to perform cost analyses of fiscal agency and review contingency plans should its current fiscal agent begin to rethink its relationship. Billing and invoicing are generally the factors associated with fiscal agency, but vendor negotiations may take more time and be more valuable for members than billing services, particularly if technology has also improved vendor invoicing and receipt capabilities. Consortial savings or cost avoidance from fiscal agency should be calculated and marketed to academic administrators. Consortia may benefit from having these savings prominently displayed on their home pages or easily accessible by Internet links.

Finally, an interesting trend is the increase in online distance education consortia.

ICCOLC is a two-year online distance education consortium that includes an important library resource component. Although electronic resources were initially purchased for the program, access to these databases is available for both in-class and distance students for all of the member colleges. Another online distance education program in Tennessee (i.e., the RODP [Regents Online Distance Program]) was discussed during the interview with a representative from the TBR Library Deans and Directors Group. As these consortia continue to grow, so do the opportunities for academic library participation. Grants or other state funding may be available for statewide resources included as part of an academic online distance learning consortium as other funding sources recede. 


\section{U.S. Academic Library Consortia: A Review}

This project reviewed only academic consortia with specific criteria including two-year college participation. In many consortia with both two- and four-year colleges, two-year colleges are seen as equal members with a prominent voice in governance. Another source of valuable information would be to examine the various roles that state libraries play in statewide electronic resource licensing. State library representatives often sit on governing boards of academic consortia as ex officio, non-voting members, and they have often played a significant role in helping to launch and grow academic consortia. The changing roles of large multi-type regional consortia (such as former OCLC regional offices) may also be helpful to analyze and study for future benefit. Additionally, one interviewee noted that an interesting exercise would be to speak to vendors about their experience with consortia.

Consortia are fluid organizations, both in their operation and function. As demonstrated in these interviews, academic consortia are changing, restructuring, growing, and sometimes divesting themselves from long-held relationships with state entities. As one consortium representative aptly noted, the way a consortium did things when it started may not be the best way to do things today. Consortia participants must recognize that their organizations will inevitably change, and that a continual review of practices and relationships is an essential exercise. 
CONSORTIAL RESOURCES

Consortia Web sites:

CARLI (Consortium of Academic and Research Libraries in Illinois)

http://www.carli.illinois.edu/

Carolina Consortium

http://library.uncg.edu/carolinaconsortium/

Community College Library Consortium (CCLC)

http://cclibraries.org/index.html

lowa Community College Online Consortium (ICCOC)

http://www.iowacconline.org/

Kansas Regents Library Database Consortium (RLDC)

http://www.lib.ku.edu/rldc/index.shtml

Library Deans and Directors Group of the State University and Community College System of the Tennessee Board of Regents

http://faculty.jscc.edu/scohen/tbrlib.html

LOUIS (The Louisiana Library Network)

http://appl003.Isu.edu/ocsweb/louishome.nsf/index

MOBIUS

https://mco.mobius.umsystem.edu/

NILRC (Network of Illinois Learning Resources in Community Colleges)

http://www.nilrc.org/

Orbis Cascade Alliance

http://www.orbiscascade.org/

SUNYConnect (State University of New York)

http://www.sunyconnect.suny.edu/

VALE (Virtual Academic Library Environment of New Jersey)

http://www.valenj.org

WALDO (Westchester Academic Library Directors Organization)

http://www.waldolib.org/ 
WISPALS Library Consortium (Wisconsin Project for Automated Libraries) http://www.wispals.org/

Wyoming Community College Library Consortium

(Webpage not public)

Other Resources:

American Distance Education Association

http://www.adec.edu/

CJC-L Listserv

http://www.ala.org/ala/mgrps/divs/acrl/about/sections/cjcls/listserv/index.cfm

International Coalition of Library Consortia (ICOLC)

http://www.library.yale.edu/consortia/

"Towards a Better Kansas Library Consortium" (Word Document distributed on 10-16-2009 to RLDC listserv; written on 10-09-2009)

United States Distance Learning Association

http://www.usdla.org/ 


\section{Library Consortium Questionnaire}

Consortium Name:

Contact Person Name:

Email:

Phone:

Web site:

1. Who makes up the membership of the consortium?

2. When and why was the consortium formed?

3. How is the consortium structured?
a. Who is the board or governing body?
b. What is the mission (is there a written mission)?
c. Is there a structured voting membership?
d. Are there membership fees?

4. Database payment structure:
a. Are formulas used to determine pay structure for databases?
b. What are the formulas (if any) that are applied?
c. Other Payment models or formulas that you use.
d. If there are other members besides 2-yr libraries, how do you work out the differences?

5. Do you have a fiscal agent for your consortium?
a. Who is it?
b. How does that work?
c. Is there a known cost involved?
d. Do you have any figures on the cost?

6. What do you see as the future for your consortium? What are your goals in the next $\mathrm{x}$ number of years?

7. What are the best things about your consortium or what are those things that work the best?

8. What are the things that are challenging about the consortium? 